\title{
PERBANDINGAN KEEFEKTIFAN PEMBELAJARAN MATEMATIKA DENGAN PENDEKATAN MATEMATIKA REALISTIK DAN KONVENSIONAL DITINJAU DARI KEMAMPUAN KOMUNIKASI MATEMATIK SISWA
}

\author{
Ahmad Zaini
}

\begin{abstract}
Abstrak
Penelitian ini bertujuan untuk mendeskripsikan dan membandingkan keefektifan pembelajaran matematika dengan pendekatan matematika realistik dan konvensional ditinjau dari kemampuan komunikasi matematik siswa.

Penelitian ini adalah penelitian eksperimen semu dengan desain nonequivalent comparison-group design. Penelitian ini menggunakan dua kelompok eksperimen. Populasi dalam penelitian ini adalah siswa kelas VII SMP Negeri 15 Banjarmasin yang terdiri dari 6 kelas. Sampel penelitian sebanyak dua kelas. Penentuan sampel diambil dengan memilih kelas secara acak untuk dikenai perlakuan dengan pembelajaran matematika melalui pendekatan matematika realistik dan pendekatan konvensional. Instrumen dalam penelitian ini berupa instrument tes kemampuan komunikasi matematika. Koefesien reliabilitas instrumen tes adalah 0,711, dengan SEM adalah 1,741. Untuk mengetahui efektif atau tidaknya pembelajaran dengan pendekatan matematika realistik dan pendekatan konvensional pada masing-masing variabel, data dianalisis secara univariat dengan statistik uji one sample t-test pada taraf signifikansi 5\%. Kemudian untuk membandingkan keefektifan pembelajaran pada pendekatan matematika realistik dan pembelajaran konvensional, data dianalisis secara multivariat dengan taraf signifikansi 5\% $(0,05)$ dan ditindaklanjuti dengan analisis secara univariat pada taraf signifikansi 0,025 untuk pengujian dua arah.

Hasil penelitian menunjukan bahwa 1) pembelajaran dengan pendekatan matematika realistik efektif ditinjau dari kemampuan komunikasi matematika; 2) pembelajaran matematika dengan pendekatan konvensional tidak efektif ditinjau dari kemampuan komunikasi matematik siswa; dan 3) pembelajaran dengan pendekatan matematika realistik lebih baik dari pembelajaran konvensional ditinjau dari kemampuan komunikasi matematik siswa.
\end{abstract}

Kata Kunci: pendekatan matematika realistik, konvensional, dan kemampuan komunikasi matematika. 
Ahmad Zaini

\section{Pendahuluan}

Matematika sebagai salah satu mata pelajaran di sekolah dinilai sangat memegang peranan penting dalam meningkatkan kemampuan siswa. Kemampuan bepikir kritis, sistematis, logis, kreatif, dan bekerjasama yang efektif dapat dikembangkan melalui belajar matematika. Oleh karena itu, pengetahuan matematika harus dikuasai sedini mungkin oleh para siswa dan pembelajaran matematika di sekolah harus mampu mengembangkan potensi yang dimiliki siswa, sehingga mereka mampu memahami matematika dengan benar.

Dalam Permendiknas Nomor 22 Tahun 2006 tentang Standar Isi, mata pelajaran matematika bertujuan agar peserta didik memiliki kemampuan, sebagai berikut: (1) Memahami konsep matematika; (2) Menggunakan penalaran; (3) Memecahkan masalah; (4) Mengomunikasikan gagasan; (5) Memiliki sikap menghargai kegunaan matematika dalam kehidupan. Dari tujuan pelajaran matematika tersebut, aspek komunikasi merupakan kemampuan yang harus dimiliki siswa sebagai standar yang harus dikembangkan.

National Council of Teacher of Mathematics atau NCTM merekomendasikan salah satu standar proses dalam pembelajaran matematika di sekolah yang berkaitan kemampuan komunikasi matematik siswa yaitu mengembangkan kemampuan siswa dalam mengkomunikasikan gagasan dengan pembicaraan lisan, catatan, simbol, tabel, grafik, diagram, atau media lain untuk memperjelas keadaan atau masalah. Menurut Ontario Ministry of Education's (2005: 20) bahwa berkomunikasi matematika adalah menyampaikan makna melalui lisan, ditulis, dan bentuk visual (misalnya, memberikan penjelasan alasan atau pembenaran hasil secara lisan atau tertulis; mengkomunikasikan ide-ide matematika dan solusi secara tertulis, dengan menggunakan angka dan simbol aljabar, dan secara visual, menggunakan gambar, diagram, grafik, tabel, grafik, dan materi konkret). Oleh karena itu, dalam pembelajaran matematika siswa perlu 
Perbandingan Keefektifan Pembelajaran Matematika dengan Pendekatan

Matematika Realistik dan Konvensional Ditinjau dari Kemampuan

Komunikasi Matematik Siswa

dibiasakan untuk memberikan argumen untuk setiap jawabannya serta memberi tanggapan atas jawaban yang diberikan oleh orang lain.

Namun kenyataannya, kemampuan komunikasi matematik siswa masih jauh dari harapan. Dari pengamatan penulis selama mengajar di Sekolah Menengah Pertama, mayoritas siswa masih lemah dalam kemampuan komunikasi matematika. Hal ini bisa dilihat dari hasil survey tes kemampuan komunikasi yang telah dilakukan penulis, menunjukan hasil yang masih rendah.

Tabel 1. Hasil Survei Tes Kemampuan Komunikasi Matematik Siswa Kelas VII-B SMP Negeri 15 Banjarmasin.

\begin{tabular}{|c|c|c|}
\hline \multirow{2}{*}{$\begin{array}{c}\text { Interval } \\
\text { Skor }\end{array}$} & \multicolumn{2}{|c|}{ Komunikasi } \\
\hline & $\begin{array}{c}\text { Banyak } \\
\text { siswa }\end{array}$ & $\%$ \\
\hline $81-100$ & 0 & $0 \%$ \\
\hline $61-80$ & 5 & $15,6 \%$ \\
\hline $41-60$ & 17 & $53,1 \%$ \\
\hline $21-40$ & 7 & $21,9 \%$ \\
\hline $0-20$ & 3 & $9,4 \%$ \\
\hline Jumlah & 32 & 100 \\
\hline
\end{tabular}

Hasil kajian lebih lanjut terhadap jawaban siswa pada soal ulangan bulanan yang berbentuk essai di SMP Negeri 15 Banjarmasin pada mata pelajaran matematika kelas VII semester 2 tahun ajaran 2011/2012 untuk materi perbandingan, menunjukkan bahwa mereka umumnya masih lemah dalam mengemukakan dan menjelaskan suatu gagasan atau ide dengan menggunakan lisan, simbol, lambang, atau notasi matematika. Siswa kurang mampu menjelaskan ide - ide dalam bentuk tulisan dan gambar, sulit menyatakan suatu diagram ke dalam bahasa simbol, dan siswa kurang mampu mengemukakan ide - idenya dengan kata - kata sendiri, serta siswa kurang mampu menyampaikan pendapatnya di dalam pembelajaran.

Kemampuan komunikasi matematika yang masih tergolong kurang tersebut perlu ditingkatkan, yaitu dengan menggunakan sebuah pendekatan pembelajaran yang dapat mendukung peningkatan kemampuan komunikasi 
matematika. Melalui pendekatan pembelajaran yang tepat diharapkan dapat meningkatkan kemampuan siswa. Pendekatan pembelajaran yang akan diterapkan memungkinkan digunakan sebagai perantara untuk dapat meningkatkan kemampuan komunikasi matematik siswa.

Salah satu penyebab rendahnya kualitas pemahaman siswa dalam matematika menurut hasil survey IMSTEP-JICA (2000) adalah bahwa dalam pembelajaran matematika guru terlalu berkonsentrasi pada hal-hal prosedural dan mekanistik, pembelajan berpusat pada guru, konsep matematika disampaikan secara informatif dan siswa dilatih menyelesaikan banyak soal tanpa pemahaman mendalam. Akibatnya, kemampuan siswa dalam bernalar, berkomunikasi dan memecahkan masalah tidak berkembang sebagaimana mestinya. (Tatang Herman, 2007: 42).

Matematika dipandang bukan untuk diajarkan oleh guru, tetapi untuk dipelajari oleh siswa. Siswa ditempatkan sebagai titik pusat pembelajaran matematika. Guru bertugas menciptakan suasana, menyediakan fasilitas, dan lainnya, sedangkan peranan guru lebih bersifat sebagai manajer daripada pengajar. Pembelajaran dilakukan dalam suasana yang kondusif, yaitu suasana yang tidak begitu formal. Siswa mengerjakan kegiatan matematika yang berbeda-beda dengan target yang berbeda-beda, sementara guru berfungsi sebagai fasilitator, sumber ajar dan pemonitor kegiatan siswa. (Marsigit: 2011). Jadi, perlu suatu penggunaan pendekatan pembelajaran matematika yang memberikan kesempatan lebih para siswa secara aktif dalam proses membangun pengetahuannya sehingga diharapkan dapat meningkatkan kemampuan komunikasi matematik siswa.

Salah satu pendekatan pembelajaran matematika untuk mengatasi masalah tersebut adalah pendekatan pembelajaran dengan Pendidikan Matematika Realistik (PMR) yang diadaptasi dari pendekatan Realistik Mathematics Education (RME). Pendekatan pembelajaran dengan matematika realistik merupakan pendekatan dalam pembelajaran matematika yang memandang matematika sebagai suatu aktivitas manusia. Lebih lanjut, Sutarto Hadi (2005: 8) mengungkapkan bahwa pembelajaran 
Perbandingan Keefektifan Pembelajaran Matematika dengan Pendekatan

Matematika Realistik dan Konvensional Ditinjau dari Kemampuan

Komunikasi Matematik Siswa

matematika realistik memiliki karakteristik dan prinsip yang memungkinkan siswa dapat berkembang secara optimal, seperti kebebasan siswa untuk menyampaikan pendapatnya dan adanya masalah kontektual yang mengaitkan konsep matematika dengan kehidupan nyata. Pendidikan matematika realistik boleh jadi merupakan suatu pendekatan yang menjanjikan dalam pembelajaran matematika. Berbagai literatur (seperti: Streefland, 1991; Gravemeijer, 1994, 1997) menyebutkan bahwa pendekatan pendidikan matematika realistik berpotensi meningkatkan pemahaman matematika siswa.

Menurut Sugiman (2011: 3) bahwa dari aspek teoretis, prinsip dan karakteristik pendidikan matematika realistik dapat dikatakan mendukung ketercapaian tujuan KTSP dalam pembelajaran matematika. Pernyataan bahwa tujuan pembelajaran matematika di semua jenjang persekolahan adalah untuk melatih peserta didik cara berpikir dan bernalar dalam menarik kesimpulan, mengembangkan aktivitas kreatif yang melibatkan imajinasi, mengembangkan kemampuan memecahkan masalah dan kemampuan menyampaikan informasi atau mengkomunikasikan gagasan sangat didukung oleh prinsip-prinsip dan karakteristik dari pendidikan matematika realistik.

Ketiga prinsip PMR dari Gravemeijer (1994: 90) yaitu guided Reinvention, Didactical phenomenology dan Self-developed models mengisyaratkan siswa harus terlibat secara interaktif, menjelaskan, dan memberikan alasan atas pekerjaannya dalam memecahkan masalah kontekstual (solusi yang diperoleh), memahami pekerjaan (solusi) temannya, menjelaskan dalam diskusi kelas sikapnya setuju atau tidak setuju dengan solusi temannya, menanyakan alternatif pemecahan masalah, dan merefleksikan solusi-solusi itu. Selanjutnya, karakteristik PMR menurut Gravemeijer (1994: 114), yaitu: (1) Menggunakan konteks lingkungan keseharian sebagai sarana belajar matematika adalah untuk membuat hubungan antara pengetahuan yang dimiliki siswa dengan yang akan dipelajarinya. (2) Penggunaan model yang diarahkan pada model konkret 
meningkat ke abstrak memberikan kesempatan kepada siswa mengembangkan penalaran dan komunikasi matematik serta kreatifitas. (3) Penggunaan kontribusi siswa yang besar pada proses belajar mengajar diharapkan mendorong kreatifitas maupun penalaran dan kepribadian siswa untuk berani dan mau berbagi pemikiran dalam menyelesaikan suatu masalah. (4) Interaktivitas yang diperhatikan dalam pembelajaran seperti interaksi, negosisasi secara eksplisit, intervensi, kooperasi dan evaluasi sesama siswa, siswa - guru. (5) Keterkaitan materi satu dan lainnya. Kondisi ini mengubah otoritas guru yang semula sebagai satu-satunya sumber pengetahuan menjadi seorang pembimbing.

Penerapan pendekatan matematika realistik memberikan harapan bagi pendidikan matematika di Indonesia untuk meningkatkan kemampuan matematis dan prestasi belajar matematika siswa. Beberapa penelitian yang telah dilakukan oleh Andriani tahun 2009, Sri Wulandari tahun 2007 dan Sutarto hadi tahun 2002 menunjukkan bahwa hasil belajar siswa dengan menggunakan PMR lebih baik daripada hasil belajar siswa yang menggunakan metode konvensional. Kemudian penelitian Sahat Saragih tahun 2007 bahwa pendekatan matematika realistik lebih baik dalam meningkatkan kemampuan berpikir logis, komunikasi matematik dan sikap positif terhadap matematika dibandingkan siswa yang pembelajarannya dengan pendekatan konvensional.

Berdasarkan latar belakang masalah, maka masalah yang akan diteliti adalah sebagai berikut: (1) Bagaimana keefektifan pembelajaran matematika dengan pendekatan matematika realistik dan pendekatan konvensional ditinjau dari kemampuan komunikasi matematik siswa kelas VII SMP Negeri 15 Banjarmasin pada materi segitiga dan segiempat? (2) Manakah yang lebih efektif diantara pembelajaran matematika dengan menggunakan pendekatan Pendidikan Matematika Realistik (PMR) dan pendekatan Konvensional ditinjau dari aspek kemampuan komunikasi matematik siswa kelas VII SMP Negeri 15 Banjarmasin pada materi segitiga dan segiempat?. 
Perbandingan Keefektifan Pembelajaran Matematika dengan Pendekatan

Matematika Realistik dan Konvensional Ditinjau dari Kemampuan

Komunikasi Matematik Siswa

Pada penelitian ini diajukan hipotesis sebagai berikut: (1) Pembelajaran matematika dengan menggunakan pendekatan matematika realistik efektif ditinjau dari aspek kemampuan komunikasi matematik siswa; (2) Pembelajaran matematika dengan menggunakan pendekatan matematika realistik lebih efektif dibanding pembelajaran matematika secara konvensional ditinjau dari aspek kemampuan komunikasi matematik siswa kelas.

\section{Metode Penelitian}

Penelitian ini menggunakan metode eksperimen semu (quasi eksperimental). Desain yang digunakan adalah desain pretest - posttest kelompok kontrol nonekuivalen (nonequivalen control groups design) dua kelompok yang sudah ada diberi pretest, diberi perlakuan (treatment) dan diberi posttest. (Gay, 1987: 289). Kedua kelompok tersebut dipilih karena setara dengan karakteristik siswa dan mendekati sama, yang membedakan adalah pemberian perlakuan pembelajaran dengan pendekatan matematika realistik dan pendekatan konvensional.

Rancangan eksperimen yang digunakan berdasarkan Nonequivalent control group design adalah sebagai berikut:

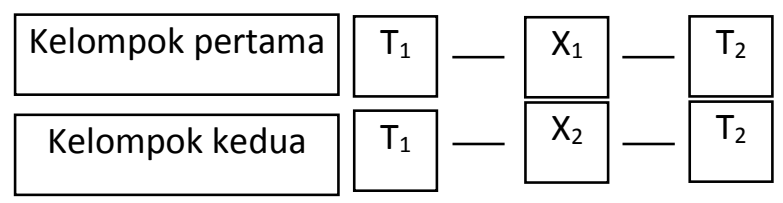

Gambar 1: Rancangan Nonequvalent Control Group Design

\section{Keterangan:}

$\mathrm{T}_{1}$ : Pretest kelompok pertama (PMR) dan kelompok kedua (Konvensional).

$\mathrm{T}_{2}$ : Posttes kelompok pertama (PMR) dan kelompok kedua.

(Konvensional).

$X_{1}$ : Penerapan pendekatan PMR.

$\mathrm{X}_{2}$ : Penerapan pendekatan konvensional.

$T_{1}: T_{2}$ (butir soal $T_{1}$ hampir sama dengan $T_{2}$ ). 
Langkah-langkah yang dilakukan dalam penelitian eksperimen berupa pemilihan dua kelompok belajar (kelas) yang diambil secara acak untuk menentukan kelompok pertama dan kelompok kedua, kemudian memberikan pretest pada waktu yang relatif bersamaan. Selanjutnya memberikan perlakuan pembelajaran dengan menggunakan pendekatan matematika realistik dikelompok pertama dan pendekatan konvensional pada kelompok kedua dilanjutkan memberikan posttets pada kedua kelompok dalam waktu yang relatif bersamaan untuk mengetahui kemampuan komunikasi matematika.

Penelitian ini dilaksanakan bulan April - Mei 2012 semester genap tahun ajaran 2011/2012. Penelitian ini dilaksanakan sebanyak 6 kali pertemuan. Populasi dalam penelitian ini adalah seluruh siswa kelas VII SMP Negeri 15 Banjarmasin yang berjumlah 6 kelas (192 siswa). Berdasarkan hasil pengacakan, kelas VII D terpilih sebagai kelas kelompok pertama yaitu pembelajaran matematika dengan pendekatan matematika realistik, sedangkan kelas VII E sebagai kelompok kedua yang menggunakan pembelajaran dengan pendekatan konvensional.

Terdapat dua macam variabel dalam penelitian ini, yaitu variabel independen (variabel bebas) dan varibel dependen (variabel terikat). Variabel bebas yaitu pendekatan pembelajaran yang terdiri atas pendekatan matematika realistik $\left(X_{1}\right)$ dan pendekatan secara konvensional $\left(X_{2}\right)$. Sementara itu, yang menjadi variabel terikat yaitu kemampuan komunikasi matematik.

Teknik Pengumpulan data dalam penelitian ini adalah tes tertulis berupa tes awal (pretest) dan tes akhir (posttest). Sedangkan instrumen penelitian yang digunakan dalam penelitian ini adalah instrumen tes bentuk uraian yang mengukur kemampuan komunikasi matematik siswa. Tes diberikan kepada kedua kelompok. Pengumpulan data kemampuan komunikasi matematik siswa dilakukan dengan memberikan tes uraian kepada siswa dengan batasan waktu tertentu. Dalam penyusunan instrument tes, terlebih dahulu disusun kisi - kisi soal kemudian menyusun 
Perbandingan Keefektifan Pembelajaran Matematika dengan Pendekatan

Matematika Realistik dan Konvensional Ditinjau dari Kemampuan

Komunikasi Matematik Siswa

soal beserta kunci jawaban. Selanjutnya pedoman pemberian skor tiap butir soal. Sebelum soal tes digunakan, soal tes terlebih dahulu dinilai validitas dan diestimasi reliabilitas. Kisi-kisi instrumen pretest dan posttest adalah memberikan penjelasan menggunakan gambar, sketsa, simbol, istilah dan kalimat, Menuliskan penjelasan atau alasan dari jawaban dan Memeriksa kebenaran/kesalahan hasil pemikiran matematis orang lain.

Instrumen tes divalidasi dengan teknik expert judgment yaitu meminta pertimbangan ahli terkait dengan validitas isi. Ahli yang memvalidasi instrumen tes adalah ibu Dr. Djamilah Bondah Widjayanti, dosen pendidikan matematika MIPA UNY. Instrumen tes dinilai valid dan dinyatakan layak digunakan menurut ahli dengan beberapa revisi. Beberapa item direvisi setelah dapat masukan dari ahli.

Untuk intrumen tes uraian, dalam mencari indeks reliabilitas menggunakan rumus alpha. (Allen\&Yen, 1979 : 83). Adapun rumus alpha Cronbach yang digunakan yaitu :

$$
\propto=\left[\frac{N}{N-1}\right]\left[\frac{\sigma_{x}^{2}-\sum_{i=1}^{N} \sigma_{Y_{i}}^{2}}{\sigma_{x}^{2}}\right]
$$

Keterangan :

$\mathrm{N}=$ Banyaknya belahan tes ,

$\sigma_{x}^{2}=$ Varians skor tes,

$\sigma_{Y_{i}}^{2}=$ Varians skor butir ke- $i$

Instrumen tes dikatakan reliabel jika koefesien reliabelitasnya $\geq 0,70$.

Perhitungan dilakukan dengan bantuan SPSS 17. Data yang digunakan untuk mengestimasi koefisien reliabilitas instrumen adalah data hasil uji coba instrumen pretest maupun posttest. Berdasarkan hasil perhitungan diperoleh masing - masing koefisien reliabilitas instrumen tes kemampuan komunikasi adalah 0,711.

Dalam penelitian ini, diselidiki efektifitas dari penerapan pendekatan pembelajaran dalam belajar matematika. Batasan yang digunakan dalam menentukan efektif atau tidaknya penerapan suatu 
pendekatan pembelajaran dilihat dari ketuntasan siswa secara klasikal dengan menggunakn acuan Kriteria Ketuntasan Minimal (KKM). Kedua pendekatan pembelajaran matematika ini dikatakan efektif jika skor memenuhi KKM yang ditentukan yaitu 65 atau lebih besar dari 64,99.

Statistik deskriptif digunakan untuk menyajikan data yang telah diperoleh melalui hasil pretest maupun posttest pada kedua kelompok dalam bentuk tabel (mean, deviasi, varian, skor maksimum, skor minimum). Menurut Suryanto (1988: 61) bahwa terdapat dua asumsi yang harus dipenuhi sedemikian sehingga uji statistik multivariate T-hotteling dapat digunakan yaitu berdistribusi normal dan terdapat kesamaan matriks kovariannya (homogen). Pada uji normalitas ini digunakan metode Kolmogorov-Smirnov. Untuk menguji homogenitas matriks varian-kovarians dilakukan melalui uji homogenitas Box-M dengan menggunakan bantuan SPSS 17. Sedangkan untuk mengetahui homogenitas varian dua kelompok dilakukan melalui homogenitas Levene's.

Data yang dikumpulkan untuk dianalisis dalam penelitian ini adalah data hasil tes kemampuan komunikasi matematik siswa melalui tes dalam bentuk uraian. Jadi, terdapat dua kelompok data sebagai hasil pengukuran yang akan dianalisis secara simultan. Kedua kelompok yaitu kelompok siswa yang belajar menggunakan pendekatan realistik dan kelompok siswa yang belajar dengan menggunakan pendekatan secara konvensional. Oleh karena itu, teknik analisis yang digunakan adalah analisis multivariat. Dengan melihat kondisi tersebut, uji statistik yang akan digunakan yaitu uji analisis multivariat dua kelompok (Two-group multivariate analysis of variance). Uji statistik ini disebut uji signifikansi beda antara dua kelompok (Suryanto, 1988: 61). Analisis multivariat dalam penelitian ini digunakan untuk menguji perbedaan rerata antara skor pretes siswa yang belajar dengan menggunakan pendekatan matematika realistik dengan siswa yang belajar dengan menggunakan pendekataan pembelajaran konvensional. Selanjutnya menguji kasus yang sama tetapi untuk rerata skor posttest. 
Perbandingan Keefektifan Pembelajaran Matematika dengan Pendekatan

Matematika Realistik dan Konvensional Ditinjau dari Kemampuan

Komunikasi Matematik Siswa

Hipotesis yang di ujikan dalam analisis multivariat adalah sebagai berikut:

a. Hipotesis kondisi awal

Sebelum diberikan perlakuan, kedua kelompok eksperimen diberikan pretes untuk mengetahui kemampuan awal siswa tidak berbeda atau seimbang. Adapun hipotesis kondisi awal siswa yaitu:

$\mathrm{H}_{0}$ :Tidak terdapat perbedaan kemampuan awal siswa pada kemampuan komunikasi matematik siswa.

$\mathrm{H}_{1}$ :Terdapat perbedaan kemampuan awal siswa pada kemampuan komunikasi matematik siswa.

\section{b. Hipotesis kondisi akhir}

Hipotesis kondisi akhir merupakan hipotesis keefektifan pendekatan pembelajaran yang diberikan pada kedua kelompok setelah diberi posttest. Hipotesis keefektifan pendekatan pembelajaran dengan matematika realistik pada kemampuan komunikasi matematik siswa sebagai berikut:

$\mathrm{H}_{0}$ : Pendekatan Pembelajaran dengan matematika realistik tidak efektif pada kemampuan komunikasi matematika siswa.

$\mathrm{H}_{1}$ :Pendekatan Pembelajaran dengan matematika realistik efektif pada kemampuan komunikasi matematika siswa.

Hal sama juga dilakukan pada kelompok kedua yaitu menggunakan pendekatan konvensional. Hipotesis keefektifan pendekatan pembelajaran dengan matematika realistik pada kemampuan komunikasi matematik siswa sebagai berikut:

$\mathrm{H}_{0}$ : Pendekatan Pembelajaran dengan konvensioanl tidak efektif pada kemampuan komunikasi matematika siswa.

$\mathrm{H}_{1}$ :Pendekatan Pembelajaran dengan konvensioanl efektif pada kemampuan komunikasi matematika siswa. 
Secara statistik, hipotesis - hipotesis di atas dapat disimbolkan sebagai berikut:

$H_{0}: \mu 0 \leq 64,99$

$\mathrm{H}_{1}: \mu 0>64,99$

Pengujian hipotesis di atas dapat menggunakan rumus t. Rumus $t$ digunakan bila simpangan baku populasi tidak diketahui. Pengujian hipotesis satu sampel dalam penelitian ini yang datanya interval atau rasio dengan menggunakan rumus berikut:

$$
t=\frac{\bar{x}-\mu}{S / \sqrt{n}}
$$

Keterangan:

$\bar{x}$ : nilai rata-rata yang diperoleh

$S$ : standar deviasi sampel /simpangan baku

$n$ : ukuran sampel

Dengan $d k=n-1$ pada taraf signifikan $5 \%$. Kriteria pengujian adalah Ho ditolak jika $t_{\text {hitung }}>t_{\text {tabel}}$.

Selanjutnya menguji hipotesis perbedaan pendekatan pembelajaran matematika realistik dan pembelajaran konvensional terhadap kemampuan komunikasi matematik siswa secara simultan. Hipotesis yang di uji adalah sebagai berikut:

$\mathrm{H}_{0}$ : Tidak terdapat perbedaan keefektifan pendekatan pembelajaran matematika realistik dan pendekatan konvensional pada kemampuan komunikasi matematik siswa.

$\mathrm{H}_{1}$ : Terdapat perbedaan keefektifan pendekatan pembelajaran matematika realistik dan pendekatan konvensional pada kemampuan komunikasi matematik siswa.

Secara statistik, hipotesis di atas dapat disimbolkan sebagai berikut:

$$
\begin{aligned}
& \mathrm{H}_{0}:\left(\begin{array}{l}
\mu P R \\
\mu K S
\end{array}\right)=\left(\begin{array}{l}
\mu P K \\
\mu K K
\end{array}\right) \\
& \mathrm{H}_{1}:\left(\begin{array}{l}
\mu P R \\
\mu K R
\end{array}\right) \neq\left(\begin{array}{l}
\mu P K \\
\mu K K
\end{array}\right)
\end{aligned}
$$


Perbandingan Keefektifan Pembelajaran Matematika dengan Pendekatan

Matematika Realistik dan Konvensional Ditinjau dari Kemampuan

Komunikasi Matematik Siswa

Hipotesis ini diuji dengan penghitungan multivariat. Uji multivariat dilakukan terhadap angka hotteling trace. Stevens (2002: 176) secara manual formula yang akan digunakan sebagai berikut:

$$
T^{2}=\frac{n_{1} n_{2}}{n_{1}+n_{2}}\left(\bar{x}_{1}-\bar{x}_{2}\right)^{\prime} S^{-1}\left(\bar{x}_{1}-\bar{x}_{2}\right)
$$

Keterangan:

$T^{2}=T^{2}$ Hotteling's

$n_{l}=$ Banyak subjek pada kelompok pertama

$n_{2}=$ Banyak subjek pada kelompok kedua

$\left(\bar{x}_{1}-\bar{x}_{2}\right)=$ mean vektor

$\mathrm{S}^{-1}=$ Invers matriks kovariansi

Hasil analisis di atas kemudian ditransformasi untuk memperoleh nilai dari distribusi $F$ dengan menggunakan rumus: $F=\frac{\left(n_{1}+n_{2}-p-1\right)}{\left(n_{1}+n_{2}-2\right) p} T^{2}$ dengan $p$ banyaknya variabel dependen, derajat bebas $v_{1}=p$ dan $v_{2}=\mathrm{n}_{1}+\mathrm{n}_{2}-p-1$. Hasil analisis kemudian dibandingkan dengan $\mathrm{F}(0,05 ; \mathrm{p} ; \mathrm{n} 1-\mathrm{n} 2)$ pada taraf sigifikansi 0,05.

\section{c. Uji hipotesis lanjutan dengan menggunakan Uji Bonferoni}

Berdasarkan hasil uji hipotesis mengenai perbedaan keefektifan pembelajaran matematika dengan menggunakan pendekatan pendidikan matematika realistik dan pembelajaran konvensional terhadap kemampuan komunikasi matematik siswa, jika terdapat perbedaan maka dilakukan uji lanjutan untuk mengetahui pendekatan mana yang lebih efektif ditinjau dari aspek kemampuan komunikasi matematik siswa secara statistik. Uji lanjut (pos hoc) dilakukan dengan menggunakan uji benferoni.

Hipotesis yang di uji untuk kemampuan komunikasi matematik adalah:

$\mathrm{H}_{0}$ :Pendekatan pendidikan matematika realistik tidak lebih efektif dibanding pendekatan konvensional pada komunikasi matematika

$\mathrm{H}_{1}$ : Pendekatan pendidikan matematika realistik lebih efektif dibanding pendekatan konvensional pada kemampuan komunikasi matematika. 
Rumus yang digunakan dalam menguji hipotesis tersebut adalah:

$$
t=\frac{\bar{X}_{11}-\bar{X}_{12}}{\sqrt{\left(\frac{S S X_{11}+S S X_{12}}{n_{1}+n_{2}-2}\right)\left(\frac{1}{n_{1}}+\frac{1}{n_{2}}\right)}}
$$

Keterangan :

$\bar{X}_{11} \quad=$ rata-rata kelompok 1

$\bar{X}_{12} \quad=$ rata-rata kelompok $\mathrm{II}$

SSX11 = jumlah kuadrat kelompok 1

SSX12 = jumlah kuadrat kelompok II

$n_{1} \quad=$ besar sampel dari kelompok 1

$n_{2} \quad=$ besar sampel dari kelompok II

kritera pengujian adalah jika $t_{\text {hitung }} \geq t_{(0,025 ;} n_{1}+n_{2-2)}$ maka $H_{0}$ ditolak.

\section{Hasil dan Pembahasan}

\section{Deskripsi Data Hasil Tes Kemampuan Komunikasi Matematika.}

Data tes kemampuan komunikasi matematik yang dideskripsikan terdiri atas data pretest dan data posttest. Secara ringkas, hasil tes kemampuan pada kedua kelompok disajikan pada sebagai berikut.

Tabel 2. Deskripsi Data Hasil Tes Kemampuan komunikasi

\begin{tabular}{|l|c|c|c|c|}
\hline \multirow{2}{*}{ Deskripsi } & \multicolumn{2}{|c|}{ PMR } & \multicolumn{2}{c|}{ Konvensional } \\
\cline { 2 - 5 } & pretes & Postes & pretes & postes \\
\hline Rata-rata & 44,81 & 70,05 & 41,15 & 58,07 \\
\hline Standar deviasi & 17 & 42 & 8 & 25 \\
\hline Nilai maksimum ideal & 100 & 100 & 100 & 100 \\
\hline Nilai minimum ideal & 0 & 0 & 0 & 0 \\
\hline Nilai maksimum & 65 & 100 & 67 & 92 \\
\hline Nilai minimum & 17 & 42 & 8 & 25 \\
\hline
\end{tabular}

\section{Analisis Data}

Analisis data yang digunakan adalah analisis statistik inferensial, merupakan analisis statistik yang digunakan untuk mengambil keputusan berdasarkan data yang telah diperoleh. Data yang dianalisis pada analisis statistik inferensial adalah data yang diperoleh sebelum maupun setelah treatment. 
Perbandingan Keefektifan Pembelajaran Matematika dengan Pendekatan

Matematika Realistik dan Konvensional Ditinjau dari Kemampuan

Komunikasi Matematik Siswa

\section{a. Analisis Data Sebelum Perlakuan}

Data yang diperoleh sebelum treatment meliputi data hasil tes

pengukuran kemampuan komunikasi matematika baik untuk kelompok Matematika Realistik (kelompok 1) maupun kelompok konvensional (kelompok 2).

\section{1) Uji Normalitas}

Uji normalitas dilakukan pada kedua kelompok yaitu kelompok yang menggunakan pendekatan matematika realistik dan Konvensional untuk mengetahui apakah populasi berdistribusi normal atau tidak. Hasil menggunakan software SPSS 17 dapat lihat pada Tabel 3 sebagai berikut:

Tabel 3. Uji Normalitas Hasil Pretes untuk Kondisi Awal

\begin{tabular}{|c|c|c|c|}
\hline Kelompok & Variabel & sig. & Kriteria \\
\hline PMR & Komunikasi & 0,609 & Normal \\
\hline Konvensional & Komunikasi & 0,610 & Normal \\
\hline
\end{tabular}

\section{2) Uji Homogenitas}

Uji homogenitas dimaksudkan untuk menguji kesamaan matriks varians-kovarians variabel-variabel dependen secara simultan (multivariat) dan untuk menguji kesamaan varians masing-masing variabel dependen secara terpisah (univariat). Hasil uji homogenitas secara simultan diperoleh adalah 0,113 dan bernilai lebih dari 0,05. Ini menunjukkan bahwa matriks varians-kovarians kelompok PMR dan Konvensional homogen.

Untuk menguji kesamaan varians untuk masing-masing variabel dependen digunakan uji Levene's. Hasil uji homogenitas secara univariat data sebelum treatment diperoleh nilai signifian 0,966 untuk komunikasi. Hal ini menunjukkan bahwa signifikansi hasil uji homogenitas univariat yang diperoleh variable komunikasi matematika lebih dari 0,05. Ini berarti varians kelompok pembelajaran PMR dan Konvensional homogen pada variabel kemampuan komunikasi matematika. 


\section{3) Uji Kesamaan Mean Sebelum Perlakuan pada Kelompok PMR dan Konvensional.}

Berdasarkan hasil perhitungan diperoleh signifikansi 0,646 (lebih dari 0,05). Ini menunjukkan bahwa Ho diterima. Dengan demikian tidak terdapat perbedaan mean antara kelompok PMR dan Konvensional ditinjau dari kemampuan Komunikasi matematika.

\section{b. Analisis Data Setelah Perlakuan.}

Data yang diperoleh setelah diberi perlakuan (treatment) meliputi data hasil posttest pengukuran kemampuan komunikasi matematika baik untuk kelompok Matematika Realistik (kelompok 1) maupun kelompok konvensional (kelompok 2).

\section{1) Uji Normalitas}

Analisis uji normalitas multivariat data setelah treatment dilakukan melalui pendekatan univariat yaitu uji Kolmogorov Smirnov. Hasil uji normalitas data setelah treatment menunjukan angka lebih besar dari 0,05 seperti disajikan pada Tabel 4.

Tabel 4. Hasil Uji Normalitas Data Setelah Treatment

\begin{tabular}{|c|c|c|c|}
\hline Kelompok & Variabel & Sig. & Kriteria \\
\hline PMR & Komunikasi & 0,376 & Normal \\
\hline Konvensional & Komunikasi & 0,819 & Normal \\
\hline
\end{tabular}

\section{2) Uji Homogenitas}

Untuk uji asumsi homogenitas, dilakukan dengan secara simultan. Hasil uji homogenitas secara multivariat setelah treatment diperoleh adalah 0,077 dan bernilai lebih dari 0,05. Ini menunjukkan bahwa matriks varianskovarians kelompok pembelajaran PMR dan Konvensional adalah homogen.

Untuk menguji kesamaan varians untuk masing-masing variabel dependen digunakan uji Levene's. Hasil uji homogenitas secara univariat setelah treatment adalah nilai signifikansi komunikasi 0,215. Hal ini 
Perbandingan Keefektifan Pembelajaran Matematika dengan Pendekatan

Matematika Realistik dan Konvensional Ditinjau dari Kemampuan

Komunikasi Matematik Siswa

menunjukkan nilai signifikansi pada masing-masing vaiabel lebih dari 0,05. Ini berarti varians kelompok PMR dan konvensional homogen variabel komunikasi matematika.

\section{3) Keefektifan pendekatan Matematika Realistik dan Konvensional ditinjau dari kemampuan komunikasi matematika.}

Uji beda satu sampel (t-tes one sample) dilakukan bertujuan untuk menguji hipotesis pertama dan kedua mengenai efektif tidaknya pendekatan matematika realistik ditinjau dari kemampuan komunikasi matematika.

a) Pengujian hipotesis dengan hasil perhitungan :

Dari hasil perhitungan diperoleh bahwa $t_{\text {hitung }}=2,249$. Jika dikaitkan dengan $t_{\text {hitung }}>t_{\text {tabel }}=2,039$, maka HO ditolak. Jadi disimpulkan bahwa rata-rata kemampuan komunikasi siswa yang menggunakan pendekatan matematika realistik lebih besar dari 64,99, atau dengan kata lain bahwa pembelajaran matematika realistik efektif ditinjau dari kemampuan komunikasi.

b) Pengujian hipotesis dengan hipotesis sebagai berikut:

Dari hasil perhitungan diperoleh bahwa $t_{\text {hitung }}=-2,180$. Jika dikaitkan dengan $t_{\text {hitung }}<t_{\text {tabel }}$, maka HO diterima. Jadi disimpulkan bahwa rata-rata kemampuan komunikasi siswa yang menggunakan pendekatan matematika realistik kurang dari 64,99 , atau paling tinggi 64,99 . Dengan kata lain bahwa pendekatan konvensional tidak efektif ditinjau dari kemampuan komunikasi.

\section{4) Perbandingan Keefektifan Pendekatan Matematika Realistik dan Konvensional Ditinjau dari Kemampuan Komunikasi Matematika.}

Untuk data yang diperoleh dari posttest komunikasi matematika setelah treatment, asumsi normalitas dan homogenitas telah terpenuhi sebagaimana telah diuraikan sebelumnya. Data yang dianalisis adalah data yang diperoleh dari posttest dan hasil pengukuran komunikasi matematika setelah dilakukan treatment. 
Berdasarkan hasil perhitungan dengan bantuan software SPSS 17 diperoleh nilai signifikansi dari Hotteling's trace 0,003 (kurang dari 0,05). Ini menunjukkan bahwa Ho ditolak. Dengan demikian terdapat perbedaan keefektifan antara kelompok pembelajaran PMR dan Konvensional apabila ditinjau pada kemampuan komunikasi matematika.

Setelah mengetahui terdapat perbedaan mean antara kelompok pembelajaran PMR dan Konvensional ditinjau pada aspek kemampuan Komunikasi matematika, maka dilakukan uji lanjut dengan kriteria Bonferroni dengan taraf signifikansinya $\alpha=0,05$ untuk masing-masing uji $t$ digunakan kriteria 0,05/2 $=0,025$. Kriteria pengujiannya adalah $\mathrm{H}_{0}$ ditolak jika $t_{\text {hitung }} \geq t_{(0,025 ; n 1+n 2-2)}=2,297$ atau nilai signifikansi lebih kecil 0,025. Hasil perhitungan menunjukkan nilai $t=2,955$. Karena $t_{\text {hitung }}$ lebih besar dari $t_{\text {tabel }}$ maka $H_{\circ}$ ditolak. Sehingga dapat disimpulkan bahwa pendekatan pembelajaran realistik lebih efektif dibanding konvensional terhadap kemampuan komunikasi matematika siswa.

\section{Pembahasan}

Berdasarkan kriteria ketuntasan yang telah ditetapkan dan hasil uji one sample $t$ test, ditinjau dari aspek kemampuan komunikasi matematik, pendekatan matematika realistik efektif, namun belum efektif pada pembelajaran konvensional. Selain itu, Uji T-Hotelling dilakukan untuk mengetahui ada atau tidak perbedaan pendekatan pembelajaran matematika realistik dengan pembelajaran konvensional ditinjau pada aspek kemampuan komunikasi matematik siswa. Uji hipotesis multivariat dengan menggunakan T-Hotelling ini, secara signifikan menunjukkan bahwa terdapat perbedaan antara pendekatan pembelajaran matematika realistik dengan pembelajaran konvensional ditinjau pada aspek kemampuan komunikasi matematik siswa. Meskipun kedua pendekatan pembelajaran terdapat perbedaan keefektifan tetapi memiliki keunggulan dan kelemahan masing-masing dan juga sintaks yang berbeda menyebabkan hasil yang berbeda pula. 
Perbandingan Keefektifan Pembelajaran Matematika dengan Pendekatan

Matematika Realistik dan Konvensional Ditinjau dari Kemampuan

Komunikasi Matematik Siswa

Hasil uji $t$ untuk aspek kemampuan komunikasi matematika menunjukan bahwa pendekatan pembelajaran matematika realistik lebih baik dibandingkan pembelajaran konvensional. Hal ini dikarenakan adanya perbedaan karakteristik pembelajaran dimana pada PMR adanya penggunaan model yang diarahkan pada model konkret meningkat ke abstrak yang memberikan kesempatan kepada siswa mengembangkan kemampuan komunikasi matematika. Siswa dituntut untuk memikirkan argumen yang mendukung penyelesaian masalah dan mengkomunikasikan proses berpikir yang mereka lakukan dalam mengerjakan soal.

\section{Kesimpulan}

Berdasarkan hasil analisis data dan pembahasan, maka disimpulkan bahwa pembelajaran matematika pada materi segitiga dan segiempat pada siswa kelas VII SMP Negeri 15 Banjarmasin dengan pendekatan matematika realistik efektif ditinjau dari kemampuan komunikasi matematik. Adapun pembelajaran matematika pada materi segitiga dan segiempat dengan pendekatan konvensional tidak efektif ditinjau dari kemampuan komunikasi matematik. Pembelajaran matematika dengan pendekatan matematika realistik lebih baik dibanding pembelajaran konvensional ditinjau kemampuan komunikasi matematik.

\section{Daftar Pustaka}

Allen, M. J. , \& Yen, W. M. (1979). Introduction to measurement theory. Monterey: Brooks/Cole Publishing company.

Depdiknas. (2006). Peraturan Menteri Pendidikan Nasional Republik Indonesia (Permendiknas) Nomor 22 Tahun 2006 Tentang Standar Isi Sekolah Menengah Pertama. Jakarta : Depdinas.

Gay, L.R. (1986). Educational research: Competencies for analysis \& application. ( $3^{\text {th }}$ ed). Columbus, Ohio : Merrill Corporation.

Gravemeijer, K. P. E. (1994). Developing realistic mathematics education. Utrecht: $C D-\beta$ press. 
Marsigit. (2011). Implementasi pendidikan karakter dalam pendidikan matematika. FMIPA. Univeristas Negeri Yogyakarta, Yogyakarta.

National Council of Teacher Mathematics (2000). Principles and Standards for School Mathematics. Reston, Virginia: NCTM.

Ontario Ministry of Education's. (2005). The Ontario Curriculum, Grades 18: Mathematics. Ontario: Queen's Printer for Ontario.

Sahat Saragih. (2007). Mengembangkan kemampuan berpikir logis dan komunikasi matematik siswa sekolah menengah pertama melalui pendekatan matematika realistik. Disertasi Doktor. Tidak diterbitkan, Universitas Pendidikan Indonesia Bandung.

Sri Wulandari Danoebroto. (2007). Pengaruh pembelajaran matematika dengan pendekatan pendidikan matematika realistik indonesia dan pelatihan metakognitif terhadap kemampuan pemecahan masalah siswa sekolah dasar. Tesis Magister, tidak diterbitkan, Universitas Negeri Yogyakarta, Yogyakarta.

Stevens, J. (2002). Applied multivariate statistics for the social sciences $\left(4^{\text {th }}\right)$. London: Lawrence Erlbaum Associates Publisher.

Sugiman. (2011). Peningkatan pembelajaran matematika dengan menggunakan pendekatan matematika realistik. Diunduh tanggal 15 Desember 2011 dari: staff.uny.ac.id/sites/default/files/tmp/2011 PPM_lceberg_O.pdf

Suryanto. (1988). Metode statistik multivariate. Jakarta: Depdikbud.

Sutarto Hadi. (2002). Effective teacher professional development for the implementation of realistic mathematic education in Indonesia. Disertasi Doktor. Tidak Diterbitkan, University of Twente, Utrecht.

, (2005). Pendekatan matematika realistik dan implementasinya. Banjarmasin: Tulip.

Tatang Herman (2007). Pembelajaran berbasis masalah untuk meningkatkan kemampuan penalaran siswa SMP. Cakrawala pendidikan, th XXVI No.l. Bandung: UPI.

\author{
Ahmad Zaini \\ SMP Negeri 11, Banjarbaru \\ E-mail: zainiahmad98@gmail.com
}

